
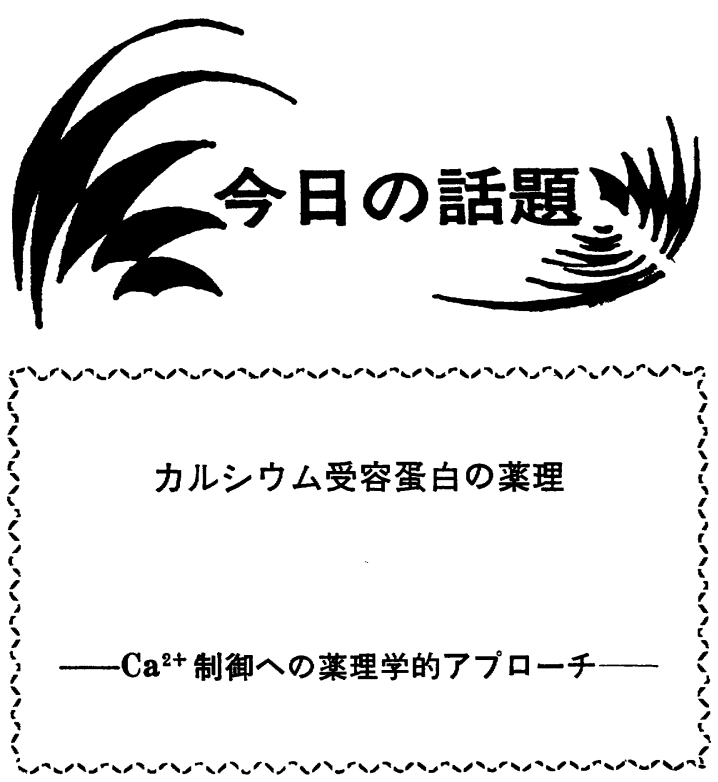

$\mathrm{Ca}^{2+}$ は cAMP などと並んで最も重要な細胞内情報伝 達物質之考えられてきたが，具体的な機序については不 明の点が多かった. しかし, 近年, $\mathrm{Ca}^{2+}$ 受容蛋白 calmodulinの発見によって，この領域の研究は非常に大き な進歩をとげた. 分子量 16,500 の蛋白である calmodulin は高等動物から下等動物まで広く種々の細胞組織 に分布することが確認され, $\mathrm{Ca}^{2+}$ の細胞内情報伝達の少 なくとも一部はこの蛋白を介して行なわれるのではない かといらのが現在の考え方である.

Calmodulin は約 10 年前, 大阪大学垣内(1), アメリカ のCheung らによって, 環状ヌクレオチド活性化因子と して報告された. 垣内はこの蛋白の活性が $\mathrm{Ca}^{2+}$ 依存性 であることをすでに記載しているが，当時 $\mathrm{Ca}^{2+}$ 依存性 に注目する人は少なく，ホスホジエステラーゼ活性化因 子として認識されたにすぎなかった. その後, この蛋白 が種々の酵素を $\mathrm{Ca}^{2+}$ 存在下で活性化することが明らか となりそとの $\mathrm{Ca}^{2+}$ 依存性に人々が注目するようになっ た. 現在, この蛋白は 1 分子当り最高 4 個の $\mathrm{Ca}^{2+}$ を結 合することができ, 結合 $\mathrm{Ca}^{2+}$ 数によって巽なったコン ホメーションをとることで, 多種類の酵素反庆に関与す ることができるのであろらと考えられている.これまで に明らかにされた calmodulin 関与の酵素のらち主なる のには, $\mathrm{Ca}^{2+}$ 依存性ホスホシェステラーゼのほか, アデ ニル酸シクラーゼ, ミオシン軽鎖キナーゼ, ホスホリラ 一ゼキナーゼ, グリコーゲンシンターゼキナーゼ, $\mathrm{Ca}^{2+}$, $\mathrm{Mg}^{2+}$-ATPase, トリプトファン水酸化酵素 リン 酸化酵
素, シナプトゾーム膜蛋白リン酸化酵素, シナプス膜蛋 白リン酸化酵素, ホスホリパーゼ $\mathrm{A}_{2}$ などがあり，これ まで $\mathrm{Ca}^{2+}$ 依存性酵素といわれていたものの中には calmodulin が酵素の $\mathrm{Ca}^{2+}$ 結合ニニットになっているすの が含まれていることが判明し，数多くの $\mathrm{Ca}^{2+}$ 依存珄現 象の少なくとも一部は calmodulin 依存性で, $\mathrm{Ca}^{2+}$ の効 果は calmodulinを介して伝えられていると考えられる ようになった.すなわち, calmodulin が細胞内 $\mathrm{Ca}^{2+}$ 受 容体として働いているのではないかとの仮説が研究者の 好奇心を刺激し, 多くの研究者が calmodulin の生理的 役割に深い関心を持つようになったわけである.

現在, calmodulin の関与が推定される生理現象とし ては，血管平滑筋の収縮，血小板の凝集ならびに放出反 応, 赤血球膜および心笳筋小胞体膜のカルシウム輸送, 微小管の脱重合, 神経伝達物質の合成と放出, インスリ ン分泌などがあるが，生体において calmodulin の関与 が直接証明されたものは少ない. そこで，薬理学的アプ ローチに目が向けられるようになったわけである.つき に，筆者らの試みてきた薬理学的アプローチの一つを紹 介し，今後の研究への展望を述べることとする.

$\mathrm{N}$-(6-aminohexyl)-5-chloro-naphthalenesulfonamide (W-7) の血管弛緩作用をしらべているらちに，筆者 らは,この薬物の平滑笳弛緩作用が種々の agonist の収 縮に対して特異性を持たず，また種々のblockerによっ ても影響されないことに注目し，この薬物の作用が膜と かレセプターの関与しない細胞内反応によるものであろ らと考え, アクトミオシン系への作用を想定した. 薬物 は血管平滑筋から調製したアクトミオシンの超沈殿現象 を抑制し，血管弛緩作用がアクトミオシンの反応性を抑 制することによる(2)ことを証明する一方，酵素系に対す る作用を検討し， $\mathrm{Ca}^{2+}$-calmodulin 依存性ホスホジェス テラーゼの特異的阻害剂であることを明らかにした． 2 つの系の実験事実から calmodulin のアクトミオシン系 への関与を確信し，これを1977 年日米合同サイエンス プログラムセミナーにおいて発表した. 㳙收縮の $\mathrm{Ca}^{2+}$ 調節はトロポニンCによるといら説が有力であった当時, 平滑筋アクトミオシン反応への calmodulin 関与を提示 したこの報告は画期的なものであり，重要な意味を持っ ていた. しかし当時, calmodulin は $\mathrm{Ca}^{2+}$-calmodulin 依存性ホスホジェステラーゼ活性化因子としてしか認識 
されていなかったため，どのようなかたらでアクトミオ シン反応に関与するかはまったくわからなかったことる あって，多くの人に注目されることはなかった。

半年後, Dabrowska らが平滑筋アクトミオシン ATPase 活性の $\mathrm{Ca}^{2+}$ 依存性がミオシン軽鎖のリン酸化によ る(3)ことを報告し，つづいてミオシン軽鎖リン酸化酵素 が $\mathrm{Ca}^{2+}$ 結合ユニットとして calmodulin を持つことに よる(4)ことを証明した. 平滑筋アクトミオシン系に関与 する calmodulin の役割が明らかにされたことによっ て, W-7 は calmodulin 機能を抑えることによってミ オシン軽鎖リン酸化反応を抑制し，その結果アクトミオ シンの収縮性が減少するために血管弛緩がおこると推論 することができ，実験的にもこれを証明することができ た(5,6). すなわち，分子レベルでの研究によって得られ た阻害凪の作用機序と阻害剂の生体に与える影響をしら べた結果から， $\mathrm{Ca}^{2+}$ あるいは $\mathrm{Ca}^{2+}$ 受容体の役割を明ら かにしたわけである. また，血小板の放出反応は血小板 凝集現象における中心的役割を果たしていることが知ら れているが，W-7 は同様の作用機序を介して放出反応 を抑制することで，血小板凝集阻害作用を発現すること を証明した(7).

生体内の特種な構成成分（酵素など）の特異的阻害剂 が生理機能に及ぼす影響をしらべることにより，生体の 機能を詳しく理解する方法は薬理学の常套手段である が, calmodulin についてもこのような方法が有効なこ とが立証された. 同様の方法は他の生命現象に対しても 有効だろう.このような薬理学的アプローチにとって最 も重要なことは, 手段として用いる薬物の calmodulin に対する特異性である.これは簡単なようで実はむずか しい問題を含んでいて，ある薬物が生体内でただ一つの 作用機序を持つことはむしろ稀で， $\alpha$-blocker が同時に 抗セロトニン作用をるつことや $\beta$-bloker で有名なプロ プラノロールの局所麻酔作用などはよく知られている.

したがって, 薬物の特異性も程度の問題であることを知 るべきであろう．つまり， calmodulin に作用する薬 物の場合も, calmodulin に対してより高い特異性を持 った薬物を探すことが必要であるばかりでなく，他の作 用がより少ない薬物を探すことも重要である. calmodulin の機能を知る手段として現在利用しうる薬物を表 に示した. これらの薬物のうち最初に発見されたのが

\section{Calmodulin 特異的阻害剂}

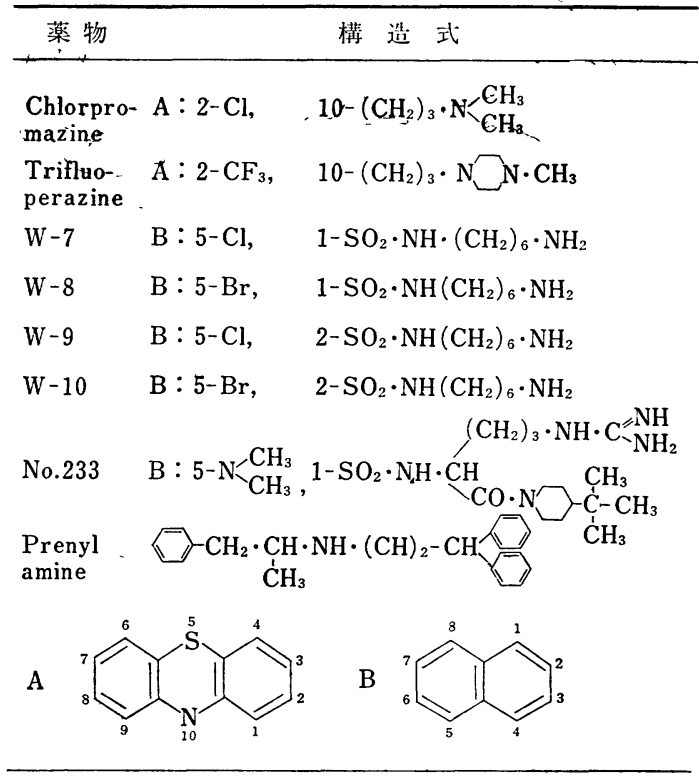

phenothiazine 誘導体である. calmodulin 発見の 2 年前 に，日本人研究者本多によってこのもののホスホジェス テラーゼ阻害作用が報告され，10 年後になって Weiss らによって calmodulin阻害作用が確認された. 彼ら は calmodulin 阻害作用を薬物の向精神作用の根拠 と しているが，これには若干の問題があり，向精神作用は calmodulin 阻害作用よりもはるかに低い濃度で発現す るため，他の作用機序によると考えるべきであろら．

今後, calmodulin への特異性が高く，他の作用をでき るだけ除くことのできる薬物を開発することができれば， 種々の生理現象における calmodulin の役割をさらに明 らかにすることができ，生体機能における $\mathrm{Ca}^{2+}$ 制御の 実態はより明確に描き出されるであろう.

1) S. Kakiuchi, R. Yamazaki \& H. Nakajima : Proc. Jap. Acad., 46, 587 (1970).

2) H. Hidaka, M. Asano, S. Iwadare, I. Matsumoto, T. Totsuka \& N. Aoki : J. Pharmacol. Exp. Ther., 207, 8 (1980).

3) R. Dabrowska, D. Aromatorio, J. M. F. Sherry \& D. J. Hartshone: Biochem. Biophys. Res. Commun., 78, 1263 (1977).

4) R. Dabrowska, D. Aromatorio, J. M. F. Sherry \& D. J. Hartshorne : Biochemistry, 17, 253 (1978).

5) H. Hidaka, M. Naka \& T. Yamaki : Biochem. Biophys. Res. Commun., 90, 694 (1979).

6) H. Hidaka, T. Yamaki, M. Naka, T.Tanaka, H. Hayashi \& T. Kobayashi : Mol. Pharmacol., 17,66(1980).

7）西川政勝, 佐々木泰治, 生川早智子, 日高弘義：血液と脈 管, 印刷中.

（日高 弘義, 三重大学医学部薬理学教室） 


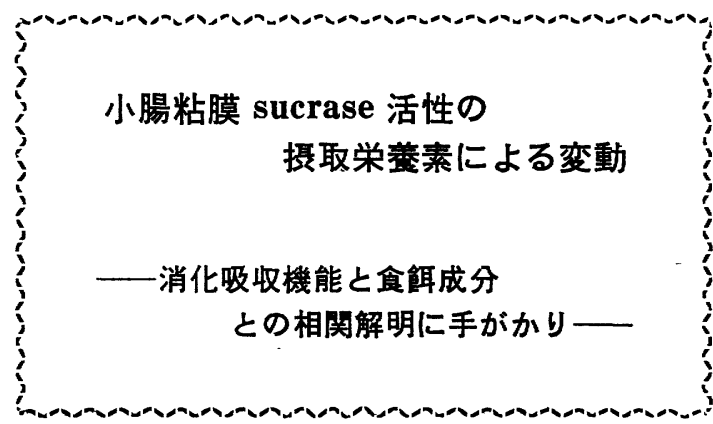

摄取した多糖類，蛋白質が消化管で消化され，最終的 に単糖, アミノ酸として血中に入ることは古くから知ら れていたが，小腸管腔内のこれらの消化過程の最終段階 は不明確であった. 近年, これら摄取栄養素の終末消化 は膜消化，小腸上皮細胞表層である刷子縁に局在する酵 素によって行なわれることが明らかにされてきた．小腸 上皮細胞表層が摂取栄養素と生体組織の具体的接点であ ることから, 生体の恒常性維持のためにも外部環境要因 である摂取栄養素組成の変動にこの膜消化の機作が積極 的に対応する可能性が示唆される. 事実，これまでに刷 子縁に局在する数種の水解酵素活性が, 基質としての栄 養素摄取により適応的に変動することが知られている. とくに，刷子縁に大部分が局在する sucrase 活性は蔗糖 摄取により上昇し，その活性と蔗糖の吸収速度との間に は高い相関のあることが認められている.

このような小腸粘膜, とくに刷子縁に限定的に局在す る酵素活性の生理的意義を示唆する知見は, 当然の推移 として栄養研究にとり入れられた。 それは，人間に和け る摄取熱量の不足を伴わない低蛋白質栄養状態である Kwashiorkor における消化管機能低下の一因として小 腸粘莫二糖類水解酵素 (maltase, sucrase) 活性の低下 が臨床的に報告されたことに端を発し，これらの酵素活 性への蛋白質栄養の影響に関する研究がラットを用いて 1970 年前後に欧米で多数行なわれた. しかし,これらの 研究に共通した結論は, 蛋白質栄養とこれらの酵素活性 との関連は見いだされず，前述の人間での現象は蛋白質 以外の栄養素の欠乏あるいは衛生状態に起因するすのと されていることである.

当時, 筆者らは 1 種類の必須アミノ酸を欠除させた不 均衡アミノ酸混合飼料および無蛋白質・無アミノ酸飼料 をラットに摄取させ，体内代謝の変動を検討していた。 この種の実験での問題は, 完全アミノ酸混合飼料の摂取
量に比べこれら試験飼料の撕取量が極端に少ないこと で, 食慨アミノ酸以外に摂取熱量の低下を考慮する必要 があった，そこで，蔗糖を炭水化物源とする完全アミノ 酸混合飼料を液状とし，胃管による飼料の強制投与条件 にラットを充分慣らしたのちに，その飼料で成長しうる 投与量と等量の不均衡フミノ酸混合飼料あるいは無蛋白 質・無アミノ酸飼料を数日投与したところ，これらの飼 料の自由摂取条件ではみられなかった下浰を伴う消化管 の異常を発現した (1). その異常は投与栄養素の小腸での 吸収不全であり，機能の異常として小腸二糖類水解酵素 活性の顕著な低下を観察したが，飼料を完全フミノ酸混 合飼料に変えたところ，1 日後には下㢉および吸収不全 が消失し，前記酵素活性も明らかに上昇した(2)。これら の現象は,ラットも人間と同様にこれらの酵素活性が蛋 白質栄養の直接的影響を受けることを示している.

以上のことから，ラットを用いた従来の研究の結論は, 本来人間の Kwashiorkor で提起された事象について単 純に蛋白質のみを問題にし，摂取熱量をまったく考慮し ない基本的な実験条件の不充分な設定のもとで導かれた ものと考えられる、また，前述の筆者らの実験では，各 試験飼料の投与量を変えると, 小腸単位長さ当りの小腸 および粘膜重量は正の関連を，一方 sucrase の粘膜ある いはその蛋白質重量当りの活性（比活性）は負の関連を 示すが，小腸単位長さ当りの活性は飼料投与量に左右さ れず一定値を示し，飼料組成だけを反映することが明ら かになった( ${ }^{(3)}$.この事実は, ラットの sucrase 活性を比 活性で示して考察した従来の研究に再検討を求めるるの であり, sucrase 活性を小腸単位長さ当りで表わすこと は，1)その活性の局在性，2)各種栄養条件による小腸重 量の著変に対して, その長さの不変，3）その比活性と粘 膜重量の経時変化での異相，などの理由から，より本質 的であると考えられる.このような活性表現によれば, 従来からの実験条件であるラットの飼料自由掑取条件に おいてる，小腸粘膜 sucrase 活性が飼料蛋白質の量およ び質 ${ }^{(4)}$ ，さらにアミノ酸補足(5)により積極的な影響を受 けること，また前述の飼料摂取量に対するこの酵素活性 の特性るこの実験条件で当てはまることが明らかになっ ている(3,5).

ところで，このような飼料撕取量の多寡に支配されな い小腸単位長さ当りの sucrase 活性の特性は, いかなる 
機序によるものであろらか. 蔗糖摂取による小腸粘膜 sucrase 活性の上昇について, Rosensweig と Herman ${ }^{(6)}$ は, 人間では小腸上皮細胞の増殖期に蔴糖の影響を受 けけ，その細胞の成熟期に sucrase 活性の上昇が発現する との仮説を提案し，他方，ラットを用いた Grand ら (7) の研究では, actinomycin D 投与による小腸上皮細胞 の migration 阻害によっても sucrase の比活性の蔗 糖摂取による上昇が影響をまったく受けないことから， 蔗糖の影響は成熟細胞が受けるとされた。絶食ラットへ の 15 時間あるいは $5 \mathrm{~g}$ の高蔗糖飼料再揟取による小腸,

粘膜重量, および小腸刷子縁に活性のほとんどが局在す る alkaline phosphatase, leucine aminopeptidase, maltase および sucrase 活性の飼料再摂取開始以後の 経時変化を調べた筆者らの結果によると, maltase と sucrase 活性以外は飼料摂取とともに上昇し, 摂取完了 直後に最高に達したのち急激に低下する. これに対し, maltase z sucrase 活性は飼料再摂取開始 20 時間後ま でまったく変動がなく，20〜24 時間後に急激に上昇する. 小腸上皮細胞の增殖, 成熟, 㔀離の全所要時間は 40〜 48 時間であり, 增殖期がそのらちの 15〜20 時間である ので, このような sucrase 活性上昇のための影響を成熟 細胞が受けることは時間的に成立しえない(8).また, Grand らの知見を再検討したところ，彼らの示したよう に actinomycin D 投与により sucrase の比活性の上昇 はまったく影響を受けなかったが，本質的活性である小 腸単位長さ当りの活性の上昇は明らかに阻害を受けてい た.さらに，増殖細胞核破壊剤である hydroxyurea 投 与, 界面活性剂による成熟細胞表層損傷による解析から も, 蔗糖の sucrase 活性上昇の影響は増殖細胞を経る ことが支持され，極く最近，Grand 自身，以前の報告に 触れずにこの機序を認める証拠を報告した(9).

このような小腸粘膜 sucrase 活性上昇の機序の特殊性 が, 同様に刷子縁に局在する alkaline phosphatase, leucine aminopeptidase 活性と異なって飼料攝取量に 対して特性を示す素因と考えられ，その詳細な機序，た とえば媒介する刺激物質の存在, 酵素蛋白質形成と活性 発現過程, 局在化などについて生理生化学分野での検討 を提案したい. 一方, 栄養学的研究における各種食餌成 分と消化吸取機能の相互性の解析に, この sucrase 活性 の特性は有力な手がかりとなるであろう.
1) T. Kimura \& M. Tahara: J. Nutr., 101, 1646 (1971).

2) T. Kimura, S. Suzuki \& A. Yoshida : J. Nutr., 105, 257 (1976).

3) T. Kimura, S. Shiosaka, A. Sakakibara, A. Matsuoka \& A. Yoshida : Nutr. Reports Inter., 14, 657 (1976).

4) T.Kimura, A.Seto, T. Kato \& A. Yoshida: Nutr. Reports Inter., 16, 621 (1977).

5) T.Kimura, T. Kato, K. Tsukazakı \& A. Yoshida: $J$. Nutr. Sci. Vitaminol., 25, 195 (1979).

6) N.S. Rosensweig \& R. H. Herman : Gastroenterology, 56, 500 (1969).

7) R. J. Grand, D. A. Chong \& K. J. Isselbacher : Biochim. Biophys. Acta, 261, 341 (1972).

8) T. Kimura, A. Seto \& A. Yoshida: J. Nutr., 108, 1087 (1978).

9) M. H. Ulshen \& R. J. Grand : J.Clın. Invest., 64, 1097 (1979).

（木村 利三, 名古屋大学農学部栄養化学教室)

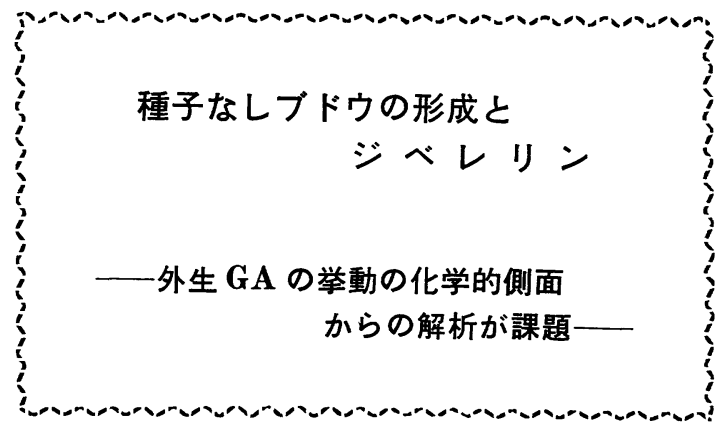

ジベレリン (GA) 処理による種子なし（無核）ブドウ の形成については, 1958 年に村西, 井上ら, 大畑らによ り最初に報告され，それぞれ別個にデラウェアを用いて， 開花前の花房処理によって種子なし果が容易に形成され ることを示した. 以後, 数年にわたって全国的に種々の ブドウ品種について応用試験が行なわれた結果, デラウ エアでは無核化ばかりでなく，熟期が $2 \sim 3$ 週間も早ま り, 経済的実用性が認められ(1,2), 農業技術として急速 に普及した. 処理技術の検討はその後も続けられ，現在 行なわれているように満開日の約 2 週間前および満開日 の $10 \sim 15$ 日後の 2 回, GA $100 \mathrm{ppm}$ を花房に浸漬処理 する方法が確立され，デラウェアの栽培面積の $90 \%$ 以 上で種子なしデラが生産されるようになった.

GA に対する反応は, 品種によってかなりの相違があ

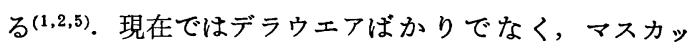
ト・ベリーAや巨峰, フレドニアなどの品種でも種子な しブドウの生産が可能となり, 一部の農家では実際に行 なわれている一方で, ナイヤガラのように高濃度の GA を処理しても無核化が困難な品種や, キャンベル・ア ーリーのように無核化は容易であるが肥大する果実の割 
合が低く，果実も小さい品種など，実用化されない品種 る多い，実用化の可能性の有望な巨峰では無核化も果実 の肥大も良好であるが，果軸の硬化がひどいため脱粒が はげしいなど，末解決の問題が残されている.

デラウエアの場合，開花前処理で無核化するとともに 無核果の肥大を誘起する. 開花後処理は肥大を促進し, 商品性のある果房を生産するのに役立っている．開花前 処理には適期があり，その重要性が指摘されている. 処理時期が適期よりもかなり早いと無核化が充分ではな く，無核になったもののうち肥大するものの割合（無核 肥大果率）が低く，その肥大る不充分である。 また，無 核果は有核果よりも着色が $2 \sim 3$ 週間早いので, 着色し た無核果に緑色の有核果が多数混入したいわゆるゴマシ オ果房となる：適期よりるやや早い時期の処理では，無 核化は充分に行なわれるが無核肥大果率が低く，無核果 の肥大も不充分で，果軸の伸長が著しいためバラ房とな る. 一方，処理時期が達れると無核化が困難となり，有 核果が多数混在する果房となる(5).

種子なしブドウが作られるには，(1)確実に無核化され ること，(2)無核化されたもののうち肥大する果実の割合 が高いこと，(3)無核果が充分に肥大すること，(4)果軸の 異常化（硬化や伸長など）が少ないこと，などの条件を 満たす必要がある．収檴期において最も良好な果房が確 実に得られるような処理時期（適期）は，満開日の 2 週 間前を中心として $3 \sim 4$ 日程度の幅しかないと言われて いるが，近年 GAに BA（6-benzyl adenine）を加用す ることによって適期幅をさらに $2 \sim 3$ 日広げる方法が実 用化された。

このように，無核果の形成と肥大のみについてみて も，処理時期や年によって天候や樹の状態により，GA に対する反応溔異が生ずるのは，花房の発育段階とそ れに伴う GA に対する生理的感受性に差異があるためと 考㝋られる.

無核化の機構については，まず開花前の GA 処理によ って花粉の呼吸活性や発芽率が著しく低下し，胚珠の機 能も低下することが明らかにされ，花粉と肧珠の両方が 機能的に障害を受けることや，GA 処理によって開花が $4 \sim 5$ 日早められ開花時に花粉は成熟段階に達している のに, 胚のうの発育は早められず開花の $4 \sim 5$ 日後に成 熟に達するため, 開花時の両者の発育段階の相違によっ
て授精がうまくゆかないことなどが原因と考えられてい $3^{(1 \sim 4)}$

GA による種子なしブドウの形成においては，開花前 に施与した GA が無核化ばかりでなく，無核肥大果率に も大きな影響を及ぼすことから，開花前処理が重要な役 割を果たしている．開花前の果房に施与した GA の生理 活性は，施与直後から急速に低下するが，低下の度合は 品種や処理後の温度条件などで異なっている．無核化も 果実の肥大もともに良好なデラウェアに和けるよりる， 無核化は良好であるが果実の肥大が不充分なキャンベ ル・アーリーのほうが，活性の低下が早く，無核化の困 難なナイヤガラではさらに早い，また，処理後の高温 $\left(30^{\circ} \mathrm{C}\right.$ 以上) は $\mathrm{GA}$ 活性の低下を早め, 無核果率，無核肥 大果率はともに低くなり，GA への BA や cAMP (cyclic AMP)の加用は GA 活性の低下を遅らせる効果があるこ とが見いだされている．これらの事実から，処理から開 花終了期頃までの GA 活性の持続性が高いほぞ，収穫時 の果房における無核果率および無核肥大果率が高くなる ことが明らかにされている(5),

施与した GA の生理活性の低下について，その内容を 検討するため， ${ }^{3} \mathrm{H}-\mathrm{GA}_{3}$ や ${ }^{14} \mathrm{C}-\mathrm{GA}_{3}$ を用いた実験では， 施与した花房においても放射活性が低下してゆくことが 報告されている( ${ }^{(6)}$ が，この活性の低下がジバン骨格その ものに関わるものなのか, 側鎖のみに関わるものなのか はまだ明らかにされていない，GA 活性の失活の過程と して，(1)処理花房において分解されて気体として放出さ れる(処理後 13 日目には処理時の $26 \%$ ), (2)結果枝の茥 葉へ移行する (同 $6 \%$ ), (2)結果枝の茎葉へ移行した後分 解，放出される，(4)結果枝以外の旧枝・幹・根などへ移 行する，などが考兄られている．また，処理した花房に 留まっているもの（同 18\%）の中には施与したままの形 で存在するるのの他に，結合型（たとえば glucoside） となって存在する可能性る考兄られる. しかし，それら を合計してる処理後 13 日目には処理時の $60 \%$ 程度しか 検出されていない，今後, 方法論も含めて検討する必要 があると思われる。

次に，果実の肥大についてみると，一般に種子のある 果実では種子で生産される生長促進物質が果実の肥大に 役立つとされている.したがって，種子が形成されない 場合には果実が肥大しないことが多い。 
無核果の肥大に和ける GA の作用については, 施与し た GA が種子で生産される生長物質の代りとして, 果肉 細胞の分裂と肥大に関与することによって果実の初期発 育を誘起し, 開花後処理の GA ととすに, 葉で生産され た同化産物の sink としての力に影響していると考えら れ，より大きな果実を得るためには開花後の処理が必要 である.

GA によって種子なしブドウを作る技術は，日本にお いて発達した技術であり, 実際栽培に広く利用されてい るにもかかわらず, 花房に施与した GA の動向やその作 用について, 化学的側面から解析を行なった報告は非常 に少ないのは不思議なことであり，ブドウに拈ける外生 GA の植物体内における代謝の過程を明らかにすること は, 今後の研究の興味ある課題であろう.

1) 岸 光夫 : 果樹試安芸津報, p. 1 (1973).

2) 村西三郎 : 九大農・学芸雑誌, 23(4), 225 (1968).

3) 杉浦 明ら : 園学雑, 35 (3), 233 (1966).

4）園芸学会編：“園芸学全編”, 養蜸堂, p. 102 (1973).

5) 元村佳恵ら : Tohoku J. Agr. Res., 23 28(1972 1978).

6) 元村佳恵ら : 園芸学会発表要旨, 昭53秋, p. 38(1978).

(元村 佳恵, 東北大学農学部)

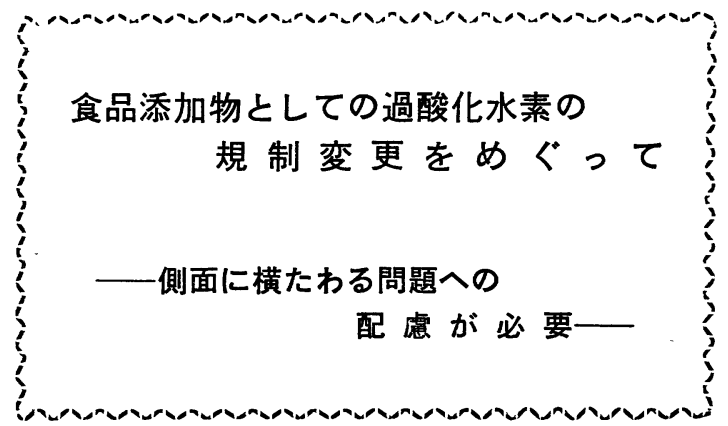

厚生省ではかねてより食品添加物などの安全性の再評

価の作業を実施しており, 発がん性をはじめ, 催奇形性, 変異原性などについて検討を進めてきている．標題の過 酸化水素については, 昭和 52 年よりマウス（広島大学 原爆放射能医学研究所の伊藤弘教授ら担当）およびラッ 卜〔(財) 癌研究会付属研究所の高山昭三副所長ら担当] を用いた発がん性の試験が開始された。

ラットについては昭和 55 年 1 月現在, なお試験を続 行中であるが， マウスについては 2 年間の投与実験を終 了し, 病理組織標本の精密検索を進めた結果, 本品に発 がん性の認められたことが昭和 55 年 1 月 11 日に厚生省 より発表された. その内容については新聞などにほぼ誤 りのない形で伝えられているのですでに御承知かと思う
が，正確を期するためにその内容を記述すると次の通り である.すなおち, 伊藤らは C $57 \mathrm{BL} / 6 \mathrm{~J}$ 系の 1 群約 100 匹のマウス 3 群に対し，それぞれ $0.1 \%$ および $0.4 \%$ の 過酸化水素水ならびに対照の無添加の水を生後 2 力月か ら26 カ月までの期間自由給水して検討した結果, 死亡 率, 血清化学的検査に打いては対照群と投与群との間に 差を認めなかったが，剖検による全身諸蔵器の肉眼的な らびに病理学的所見の観察においては, 24 力月の投与期 間中，投与群に腺胃でのびらんと潰瘍性病変ならびに十 二指腸での隆起性病変の高頻度の発現が認められた.す なわち, 胃のびらんと潰瘍性病変は $0.4 \%$ 投与群で 41 $\%, 0.1 \%$ 投与群で $20 \%$ の動物に発現し，いずれる対照 群の発現率 $4 \%$ にくらべて統計学上有意の差を示した. 一方, 十二指腸での過形成(隆起性病変の一種) は, 0.4 \%投与群で $62 \%, 0.1 \%$ 投与群で $40 \%$ の動物に発現し, いずれも対照群の発現率 $9 \%$ にくらべて統計学上有意の 差を示した. また，十二指腸の腺がんは，0.4\% 投与群 で $5 \%, 0.1 \%$ 投与群で $1 \%$ の動物に発現し, 詨照の発 現率 $0 \%$ にくらべて，0.4\% 投与群では統計学上有意の 差を示した.

以上の結果を受けて，厚生省は国立がんセンター研究 所の杉村 隆 所長らのがん研究の専門家による検討会を 開催し, あらゆる角度から討議した結果, 強いものでは ないが本品の発がん性は明白であるとの結論に達し，前 述の通り, 55年 1 月11日に厚生省環境衛生局長より, 本 品が食品中に残留することは好ましくないので, 食品加 工上可能な限り使用しないよう関係省庁の協力を得て食 品加工業者にとりあえず要望することと致したいとの談 話が発表された.この内容については, 同日付で厚生省 より都道府県, 政令市などに通知された。

一方, 食品衛生調查会は, 昭和55年 1 月30日に開かれ た会合でこの問題について討議した結果，厚生省が 1 月 11日にとった措置は，とりあえずの措置としてこれを妥 当なものであると認めた上で, さらに本品の使用が食品 の殺菌方法として果たしてきた食品衛生上の有用性につ いても十分に評価した結果, 過酸化水素を食品添加物と して使用する場合, 最終食品に残留する形で使用するこ とは適当でないとの意見具申を厚生大臣に対して行な った.

これを受けて，厚生省は「食品，添加物等の規格基 
準」の一部を昭和 55 年 3 月 20 日厚生省告示第 24 号を以 て改正し, 従来「過酸化水素及びこれを含む製剤は食品 中に過酸化水素として，うぞん，かまぼこ及びちくわに あってはその $1 \mathrm{~kg}$ につき $0.1 \mathrm{~g}$ 以上, その他の食品にあ ってはその $1 \mathrm{~kg}$ につき $0.03 \mathrm{~g}$ 以上残存しないように使 用しなければならない」と定められていたのを，「最終 食品の完成前に過酸化水素を分解し, 又は除去しなけれ ばならない」と改めた. なお，この改正は 55 年 10 月 1 日より適用することになっている（他の食品添加物で分 解除去を義務づけているものとしては亜塩素酸ナトリウ ムの例がある).

ところで, 食品中の過酸化水素の分析法としては, 昭 和 51 年 3 月 9 日環食化第 65 号(1)で通知した硫酸チタン 法による定性試験およびよう素法による定量試験が一般 に用いられているところであるが，この方法では普通 5 〜10 ppm までが定量可能とされており, また他の方法 も種々報告されているが，いずれも 1～3 ppm ぐらいを 定量限界としている. それでは, 新しい使用基準は, 最 終製品にこのような方法を適用して過酸化水素が検出さ れないよらな条件でならば過酸化水素を引続き食品加工 などに使用してるよいと解釈できるのであろうか. い や，改正の骨子は単に現在ある分析技術によって過酸化 水素が検出されないことのみではなく, 食品の製造技 術, 加工技術, 工程管理をも包含して評価して, 最終食 品中に過酸化水素の残留がないことが確実でなければな らないことを意味するものである(2). したがって，分析 方法の位置づけは，あくまです便宜的なチェック方法と して用いるものであるが，この分析法についても，環境 試験法では ppb レベルの過酸化水素の分析法が開発さ れているので, 食品分析においてもさらに高い感度の分 析法の確立をはかるべく努力中である.

ここまで説明すると，「それでは実際問題として過酸 化水素は事実上使用禁止ではないか」との質問がはね返 ってこようが，これに対しては等者は，「現状では，その 通りである」と答えることにしている. それならば，一 層のこと，食品添加物のポジティブリストから削除して しまった汪うがすっきりするではないかと，読者は考光 られるかも知れないが，この点については慎重な対処が 必要であると考える. アメリカの連邦食品薬品法には, 1958年の改正の際に“がん条項”とも乎ばれる “Delaney
(デラニー)条項”が新設され，いかねる添加物も，その 物質がいかなる使用量で使用された場合であっても，人 間または実験動物に対してがんを形成しらる場合には, または他の適当な試験で発がん性のあることが示された 場合には，食品に対する使用を許可されないことになっ ている.この観点に立つと, 添加物は意図的に食品に加 えられるものであるから, 発がん性のあるものは一切排 除すべきであるという考え方も正論として理解されよ 5 .

しかし，発がん物質といえども無作用量は明らかに存 在するのであるから，今後は食品中の発がん物質にも闘 值という概念を取り入れるべきであろう，成人がうどん 換算で 1 日 $1 \mathrm{t}$ 撽取した場合と想定される苛酷な条件下 での発がん性でも，実質的には使用禁止と見なされる処 置をとらざるを得ないのが現状であるが，食品添加物の 安全性についての洗い直しで, 今後も微弱な発がん性が 認められる物質の出てくることも予想されるので，代替 品の有無, 禁止した場合の消費者に与えるデメリットな そも考慮して, 発がん性も定量的に評価すべき時代が遠 くない将来に必ず来ると筆者は確信する. したがって, 今ここで過酸化水素を食品添加物のリストから削除して しまらと，永久に抹殺されてしまうことになるので，し ばらく凍結しておこうではないかということである。

なお，これは食品添加物としての過酸化水素と直接の 関係はないが, 本品は食品の器具（運搬容器, 食品製造 機械，ちゅら房具, 割ぼう具など)および容器包装の殺 菌剂としても広く使用されている. 現在, 食品衛生監視 に当っては, 器具・容器包装の殺菌にも食添規格にあっ た過酸化水素を使用するように指導している（食添規格 では, 安定剤としてのりえ酸塩は約 $55.3 \mathrm{ppm}$ 以下, 蒸 発残留物は約 $265.5 \mathrm{ppm}$ 以下と定められている). した がって, 食品添加物公定書の過酸化水素の規格が削除さ れてしまって, 工業薬品の未知の安定剤を含んだ製品が 器具なとの殺菌に用いられることになれば, 食品衛生上 大きなマイナスになるので，そのためにも公定書の過酸 化水素の規格はよりどころとして残しておかなければな らないわけである.

1）厚生省食品化学課：食品衛生研究，26，593 (1976).

2）入村和子：食品衛生研究，30，357 (1980).

(慶田 雅洋, 国立衛生試験所大阪支所) 